\title{
THE HUNGARIAN GOVERNMENTAL DEFENCE AND MILITARY DEVELOPMENT PROGRAM "ZRÍNYI 2026" AS A RESPONSE TO THE NEW THREATS IN THE REGION
}

\author{
Olivér BALOGH \\ WOJSKOWA AKADEMIA TECHNICZNA
}

\begin{abstract}
The purpose of the article is to illustrate the Hungarian Governmental Defence and Military Development Program „Zrínyi 2026”, enacted in 2016, and its role in national and regional European security. The author focuses not only on the military technical changes, that include addition of the new equipment, but also discusses the organizational and structural changes promoted by the program. Presented analysis also elaborates on the defence budget and its forecast up to 2024, with discussion on major implications. Thorough this emphasis structure of the Armed Forces of Hungary, as of January 2019, is presented, in view of changes caused by modern threats in the region.

Keywords: Hungarian Defence Forces, defence budget, military subsystem, modernization program, security.
\end{abstract}

\section{Introduction}

The Hungarian Defence Forces (Magyar Honvédség) celebrated its 170-year anniversary in 2018. The word "honvéd" has its genesis dating back to the time of the Hungarian Uprising in 1848-1849. In 1848, the word "honvéd” was used for the first time, containing special patriotic meaning in the form of active participation of the defence of the Motherland (Homeland). The idea of „honvéd” was expressed in the call of the Hungarian Defence Forces: „For the Motherland”.

The new international situation - like the increase of defence expenditures at the international level, asymmetric and hybrid threats, migration crisis - has forced Hungary, a relatively small country in Central Europe, to start modernization process of its Army. The modernization program of the Hungarian Defence Forces is the first breakthrough program since the 1990s. Therefore, the main focus is on the analysis of media articles about modernization program "Zrínyi 2026”.

The author, on account of his knowledge of the Hungarian language, used Hungarian literature to present current structure of the Hungarian Defence Forces, what allows for the unambiguous presentation of the changes that took place by the year of 2018. Major attention is given to the defence budget, which is necessary for 
any development of military forces. After all it was Napoleon Bonaparte, who said: "For war we need three things money, money and more money." That's also true for the modernization of defence forces, and that is the reason why author underlines this aspect in this article.

In December 2018 an amendment to the Act on the Hungarian Defence Forces was passed. These changes came into force on 1 January 2019. The amendment concerns a new command structure and competence, as described below.

\section{Hungarian military subsystem}

The military subsystem comprises the Hungarian Defence Forces, which has constitutional tasks of defending the independence, sovereignty and security of the people and State. The overarching objective of this subsystem is to maintain independence, sovereignty and territorial integration of the State, and to actively participate in maintaining international peace, including the European stability assurance. To achieve these strategic objectives, the constant readiness of the defence forces is indispensable ${ }^{1}$.

Hence, defence forces have two basic functions: external and internal. The external function was defined as "counteracting against military and political threats". The internal function, on the other hand, is aimed at creating a maintaining the country's security on the international arena ${ }^{2}$.

In Hungary, the Head of the Hungarian Defence Forces is the President, what is similar to solutions known in Poland. His task as the Superior of Defence Forces are limited, however. The most important tasks include ${ }^{3}$ :

- Confirmation of the operational plans for the State defence;

- Appointments, and reversals, of the Chief of General Staff ${ }^{4}$;

- Banner assigning to the military units.

The task of appointing the Chief of General Staff increases the importance of President, since according to the new structure of the Defence Forces, the Chief of General Staff is the Commander of the Armed Forces, which implies the centralization and integration of command over the army. The article will continue to use the notion of the Commander of the Hungarian Defence Forces in the shorter form of "Commander").

The tasks of Hungarian Defence Forces see in the Constitution of Hungary [online], [access: 17.12.2018], [in:] http://libr.sejm.gov.p1/tek01/txt/konst/wegry2013.pdf

2 Z. Ciekanowski, System obrony jako element kształtowania bezpieczeństwa państwa, (edit.) R. Wróblewski, H. Wyrębek, Determinanty bezpieczeństwa militarnego, Wyd. Uniwersytet Przyrodniczo-Humanistyczny w Siedlcach, Siedlce 2016, p. 23.

3 J.Z. Tóth, A Magyar Honvédség, a Rendörség és a Nemzetbiztonsági Szolgálatok, (edit.) A. Patyi, A. Téglási, Államtan és a Magyar Âllam szervezete, Wyd. NKE, Budapest 2013, p. 259.

4 After the amendment, the position of the Chief of General Staff will remain but will be combined with the Commander of the Hungarian Defence Forces. In the amendment a new terminology of the Commander of the Defence Forces uses instead of Chief of General Staff. In the act, the term of General Staff will be abolished, instead of Staff there will be a Command Centre of the Hungarian Defence Forces (Headquarter). 
The National Assembly and the Government plays more vital role, nonetheless. The most important competences of the National Assembly are as follows ${ }^{5}$ :

- Decides to declare war and make peace;

- Accepts the military budget;

- Proclaims state of emergency;

- Decides to participate in military operations;

- Decides on number of troops of the Hungarian Defence Forces;

- Supervises by National Defence Committee the activities of the Armed Forces and assures the civilian control over it.

The government's tasks in the national defence include ${ }^{6}$ :

- Decisions to use troops for foreign missions;

- Determining the competences of the Minister of National Defence;

- Preparation of the National Defence and National Security Strategy;

- Preparation of the civil protection plans;

- Decisions to raise the level of combat readiness;

- Operational management of synchronizing economic and defence potential;

- Operational management of national awareness and defence trainings;

- Preparation the NATO Response System for national purposes;

- Annual reporting to the National Assembly on the actions and directions taken in development of the Hungarian Defence Forces.

Next to the most important tasks and competences of individual State authorities listed above, there are also those authorities managing the subsystem, which has the greatest impact on development, operations, and in the defining the tasks of the armed forces. Among those, there is the Minister of National Defence, who directly organizes the Armed Forces. The most important tasks of the minister include ${ }^{7}$ :

- Execution of operations involving the armed forces, such as war, and crisis situations;

- Implementation of the Government's assumptions, decisions and resolutions regarding national defence;

- Supervising the implementation of activities for military tasks the State administration units, state institutions, local governments and business entities;

- Synchronizing cooperation between military units, finalizing international agreements regarding the participation of Hungarian military contingents in international missions;

- Managing the activities of maintaining security in the airspace;

- Managing the activities of equipment purchase, conducting research, carrying out equipment repairs, removing obsolete equipment;

Ibidem, p. 258

6 The Act of Hungarian Defence Forces [online], [access: 17.12.2018], [in:] https://net.jogtar.hu/jogszabaly?docid=A1100113.TV

7 Z. Szenes, Honvédelem - védelempolitika, Wyd. Dialóg Campus, Budapest 2017, p. 69-70. 
- Creates and discharges troop units in the structure of the Hungarian Defence Forces;

- Manages the maintenance and protection of strategic facilities in the ensuring state defence (critical infrastructures).

At the end of 2018, the Minister of National Defence submitted an initiative to change the management and command structure of the Hungarian Defence Forces. The changes came into force on 1 January 2019. The direction of changes will introduce centralization and integration of command over the army, signifying more competences for the Commander of the Hungarian Defence Forces, where he is, as the commander-in-chief of the army, the commander of the defence forces during peace and war. It is important to underline that based on the new changes, the Command Centre will be separated from the Ministry of National Defence, and is becoming a separated body within the military subsystem. This situation will result in a clear hierarchy in commanding the forces.

The competences of the Commander of the Hungarian Defence Forces include $^{8}$, among others:

- Commands the Hungarian Defence Forces during peace and war, prepares a command structure;

- Prepares operational plans and prepares troops to defend the country and proves actions;

- Designates number of persons and units for active service.

In Hungary, different from the Polish system, there is no position of the Supreme Commander. As in the peace, and during war, the powers of the Supreme Commander belongs to the Commander of the Hungarian Defence Forces.

\section{Forecasting the military expenditure situation in the years of modernization program}

Conflicts and civil war in Ukraine that have been going on since 2014 have stimulated the North Atlantic Treaty to take actions in order to increase the sense of security. To this end, a decision was made to confirm the minimum threshold for the military expenditures during the NATO Summit in Wales in 2014. In the summit the defence budget was established on the threshold of $2 \%$ of the GDP, which member states should reach by 2024 . To reach this objective, Hungary should take drastic measures that were missing until 2016. According to the statement of the Minister of National Defence (István Simicskó), from 2016 every year the government planning should increase the defence expenditure by $0,1 \%$ of GDP, so by the government plan, the goal of $2 \%$ of GDP should be reached by the 2026 . However,

The Act of Hungarian Defence Forces [online], [access: 17.12.2018]. 38/A. §, https://net.jogtar.hu/jogszabaly?docid=A1100113.TV. 
based on the new decisions by a new Minister (Tibor Benkö), the defence budget may reach this goal in 2024 or even earlier.

It was established during the meeting of defence ministers in Brussels in February 2018, that by 2024 the military expenditure in every member state would reach $2 \%$ of GDP, which is a great challenge for Hungary, considering that in 2018 the military expenditure was slightly above the $1 \%$ of GDP. The Parliament approved budgetary plans called "healthy and reasonable" with the following distribution of financial resources: $30 \%$ - for development and modernization, $30 \%$ - for the maintenance of military technology, $40 \%$ - for personal benefits and other material expenses. These decisions affect the entire Hungarian Defence Forces, taking into account the defence budget of 2018, where the structure was as follows (in percent): 39,6 - for personal expenses, 37,7 - for the maintenance of weapons and equipment, 22,7 - for the modernization of the armament's technology. On the basis of analysis of the above data, it can be stated that budget structure has not yet achieved the political objectives, but it can be a good guideline in the event of an increase in the military expenditure.
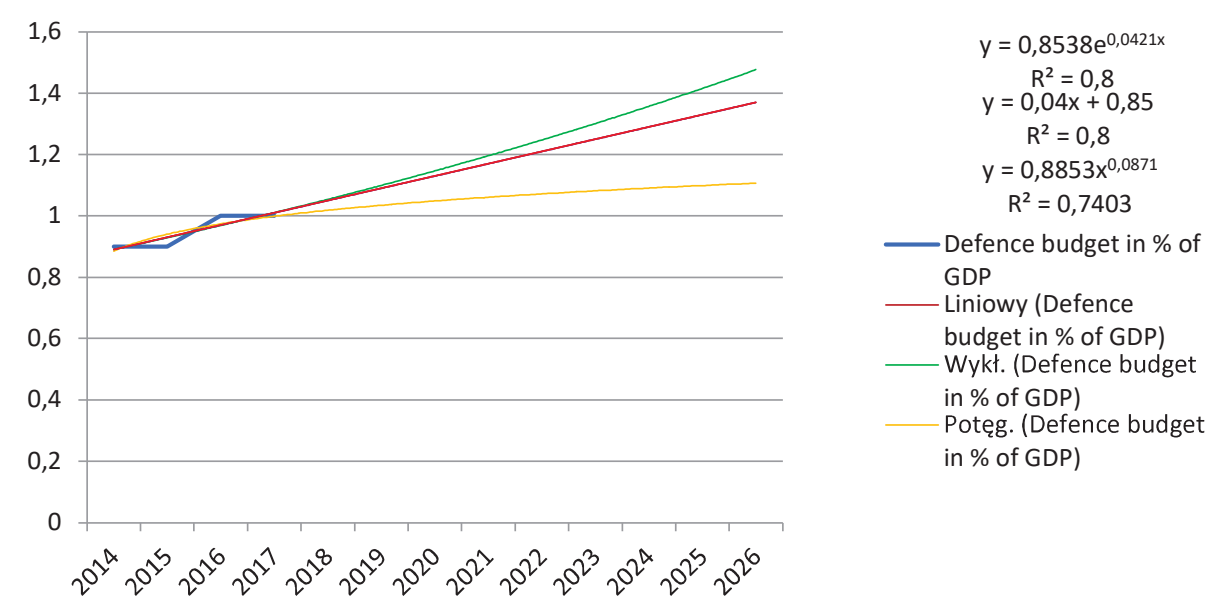

Chart 1. Forecast for the military expenditure in \% of GDP to 2026 Own elaboration based on: [online], [access: 28.11.2018], https://www.sipri.org ${ }^{9}$

In the next part, by means of statistical data and forecasting functions, it will be presented how the military budget could change until 2024-2026. The analysis did not take into account random events that may result from political decisions.

The graph above shows that in the case of a linear trend (red line) and exponential trend (green line) the coefficient of determination is 0.8 , which is the best result.

The higher the $R^{2}$ value (coefficient of determination), the better the model fit to the data. If $\mathrm{R}^{2}=1$, then all points in the series are on the straight line. 
The forecast for 2026 shows a clear rise in the defence budget, but it will not reach the target of $2 \%$ of GDP. However, caution resulting from random events should be used to display forecasts. For random events in the defence budget we can include: crisis situations (for example global financial crisis), and a positive event, i.e. economic growth, which will allow for a drastic increase in the military expenditure. On the basis of analysis, it appears that the defence budget of the Hungarian Defence Forces in 2026 will reach about $1.5 \%$ of GDP.

The objective of achieving $2 \%$ of GDP on defence as determined at the Wales Summit in 2024 is a great challenge not only for the State, but also for the national economy. In order to, achieve the NATO guidelines, Hungary should annually approximate more than $1 \%$ of GDP (as of 2016). This trend is shown in the chart below:

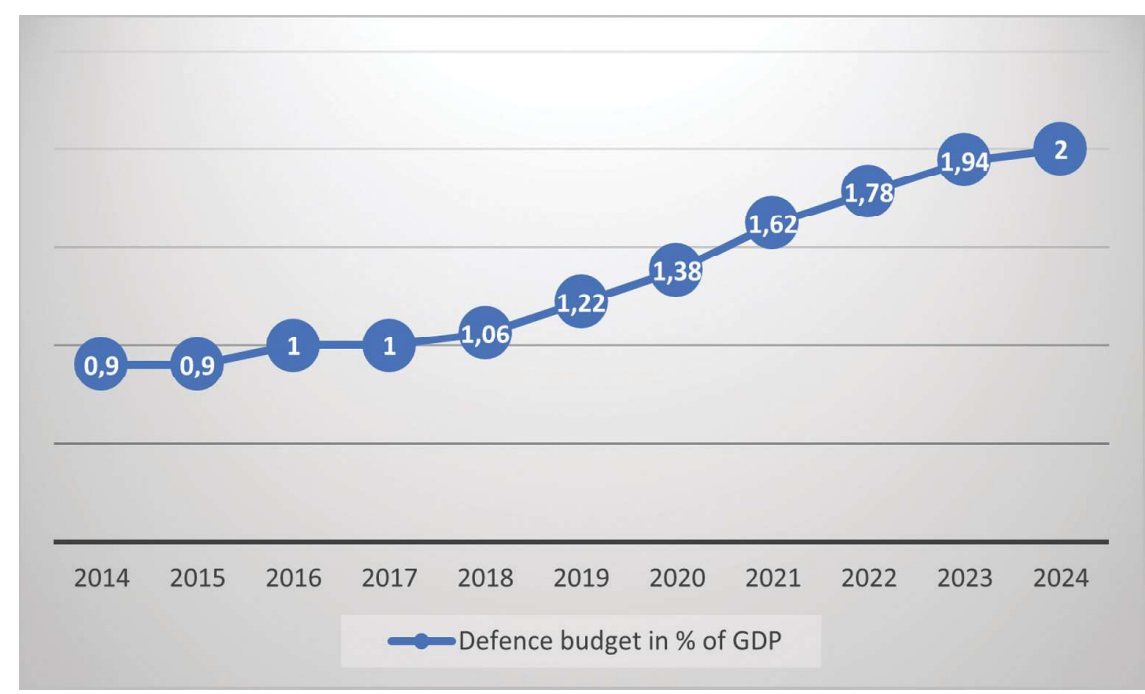

Chart 2. The forecast of Hungary's defence budget until 2024 according to the decisions of the NATO Summit in Newport

Own elaboration

According to the defence budget of Hungary in 2018, 427.334 billion forints are allocated for defence (in USD it is 1530 million). This means an increase of 265 million USD compared to 2017.

\section{Structure of the Hungarian Defence Forces}

Resolutions of the defence budget contain data on the numerical structure of the armed forces. In 2017, 25733 people were employed/worked in the organizational units subordinate to the Minister of Defence - this means an increase of 200 people compared to $2016^{10}$. The Staff of the Hungarian Forces assumed 26753 posts -

$\overline{10}$ Military expenditures from 2017 [online], [access: 11.12.2018], http://www.parlament.hu. 
in 2018 - what means increase of 1020 compared to $2017^{11}$. Based on National Assembly's Decision on the organizational structure and number of posts in the army, $29700^{12}$ were mentioned, which corresponds to the size of the army mentioned in the government program "Zrínyi 2026”.

In 2018, a decision was taken to increase the number of posts in the Hungarian Defence Forces, which is presented in the table below with the structure in force since 2013. The table contains statutory figures and does not include the position/ services unemployed.

Table 1. Anticipated composition of the Hungarian Defence Forces based on the Decisions of the National Assembly from 2013 and project by 2018

\begin{tabular}{|l|c|c|c|}
\hline \multicolumn{1}{|c|}{$\begin{array}{c}\text { Service } \\
\text { positions }\end{array}$} & $\begin{array}{c}\text { Numbers } \\
\text { by the Decision } \\
\text { from 2013 }\end{array}$ & $\begin{array}{c}\text { Project } \\
\text { of the new Decision } \\
\text { by 2018 }\end{array}$ & $\begin{array}{c}\text { Percentage of all } \\
\text { official positions } \\
\text { in the Armed Forces }\end{array}$ \\
\hline Officers & 5690 & 6600 & - \\
\hline $\begin{array}{l}\text { Non-Commissioned } \\
\text { Officers (NCO) }\end{array}$ & 8845 & 10200 & At most 33\% of all \\
\hline Enlisted personnel & 7895 & 13200 & At most 30\% of all \\
\hline Cadets & 500 & 800 & - \\
\hline NCO cadets & 100 & 250 & At most $25 \%$ of all \\
\hline Civil workers & 6670 & 6600 & \\
\hline All & 29700 & 37650 & \\
\hline
\end{tabular}

Own elaboration based on: 35/2013 Decision of the National Assembly of 16 May 2013 on the numbers and composition of the Hungarian Defence Forces, [online], [access: 12.12.2018] https://mkogy.jogtar.hu and the project, [online], [access: 12.12.2018] http://www.parlament.hu/ irom41/02163/02163.pdf

Based on the table above, we can deduce the statutory growth of military positions by around 8000 posts, without increasing the number of civilian employees - even decreasing. The numerically highest increase can be seen in the numbers of enlisted personnel with around 4000 more soldiers. However, proportionally the highest increase shows on the number of NCO cadets, amounting to $150 \%$ growth. Analysing these data's, we can conclude that the statutory number of soldiers is growing drastically and implies also changing the tendencies. We should remember that the number of soldiers were decreasing drastically since 1990s, the new project shows first time such a huge increase showing real changes in the structure of the Hungarian Defence Forces.

$\overline{11}$ Military expenditures from 2018 [online], [access: 11.12.2018], http://www.parlament.hu.

12 35/2013 Decision of the National Assembly of 16 May 2013 on the numbers and composition of the Hungarian Defence Forces, point 1, [online], [access: 11.12.2018], https://mkogy.jogtar.hu. 
In order to present the entire Hungarian Defence Forces numerical structure, it's inevitable to present the situation of reservists. The maximum statutory number of reservists in the army is 20000 , which is not part of the above structure. In Hungary, in order to encourage participation in the reserve services, the government created, similarly to the Polish system, the Voluntary Territorial Defence Reserve System. The number of reservists in October 2018 reached 8 thousand ${ }^{13}$. A part of the new system on 1 January 2017 there were established organizational frameworks of the 197 district companies. "In the Volunteer Territorial Defence Reserve - which is the third element of the reserve system, besides the systems of Volunteer Defence Reserve and Volunteer Operational Reserve, training for the applicants is provided by the training companies, including also sports company set up to support sporting activities"14.

At the main level of administration, a decision was made - in 2018 - to create a more effective command of the defence forces. After the parliamentary elections, Tibor Benkö, the prior Chief of General Staff became the new Minister of National Defence. This meant changing tendencies which characterized the military management before. Transferring political power to a person who went through all military ranks provides a more effective management and guidance for the army. The new changes that have been set will cause transferring the Headquarter to Székesfehérvár, where until 2018 the General Command Centre of Hungarian Defence Forces was located. An important change is the integration of two positions giving them to one person's hand what mean real centralization the command of the army. In the Hungarian literature from 2019 will use Commander of the Hungarian Defence Forces except Chief of General Staff. These changes came into force on January 1,2019. The new Commander will command and lead the types of defence forces (air and land forces) with the cooperation with commanders of land and air forces ${ }^{15}$. This provides a disintegration of the Ministry of National Defence and the Command Centres (Headquarters) which creates such a situation that the Ministry will manage and direct, but the Commander will command the Hungarian Defence Forces.

For reasons of major changes structure of army, it will only possible in the future to prepare a new organizational chart. In order to better illustrate this structure, the maps below present the dislocation of land and air forces units. The air bases concentrate in the middle of Hungary, in the lowlands. Most of the land forces are concentrated in the middle and east part of the country. The Hungarian role in the NATO operational activity mostly concentrates in the logistics tasks which shows the type of military exercises that took place in the country.

On the basis of the statement by the Minister of National Defence, the location of individual units will not change. However, there are plans to create a heavy brigade,

13 Megalakult az új területvédelmi ezred, [online], [access: 17.12.2018], http://www.kormanyhivatal.hu/hu/baranya/hirek/megalakult-az-uj-teruletvedelmi-ezred.

14 F. Végh, A Magyar Honvédség 1989-2017, (edit.) J.F. Holló, J. Isaszegi, L. Négyesi, A Magyar Honvédség 170 éve, Wyd. Zrínyi, Budapest 2018, p. 337

15 46-47.§ CXIII National Defence Act, Hungarian Defence Forces and measures taken during the crisis states [online], [access: 17.12.2018], https://net.jogtar.hu/jogszabaly?docid=A1100113.TV. 
and for this purpose modernization of overused technologies has begun. This action is needed to upgrade the capabilities of land forces dominated by light brigades. The brigade is to be ready to serve until $2028^{16}$.

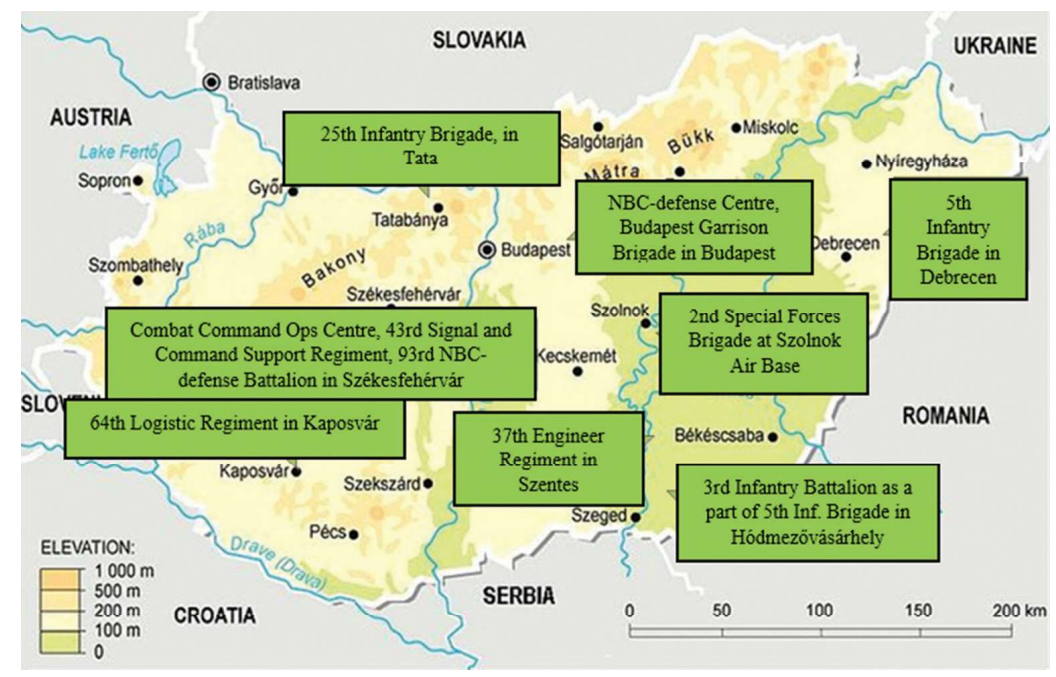

Map 1. Dislocation of land forces from (from 2016)

Own elaboration based on: (edit.) Z. Orosz, A. Szabó Szabóné, V. Resperger, A Magyar Honvédség évkönyve 2016, Wyd. Zrínyi, Budapest 2017, p. 14

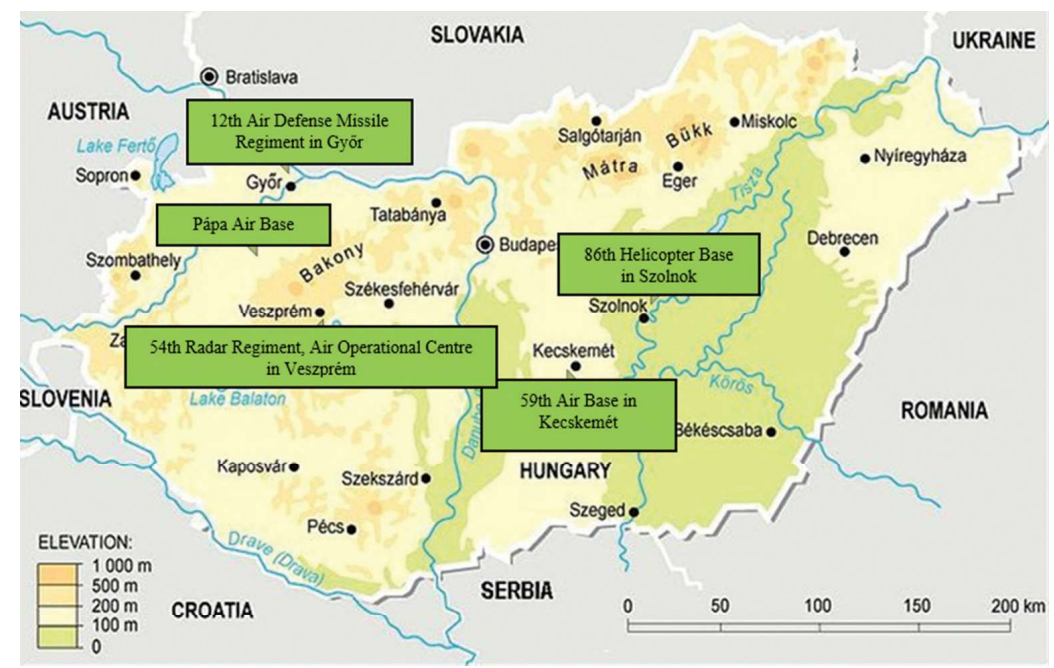

Map 2. Dislocation of air forces (from 2016)

Own elaboration based on: Z. Orosz, op. cit., p. 14

16 Statement of hte Minister of National Defence in one of the Hungarian radios (InfoRádió), [online], [access: 06.01.2019], https://infostart.hu/belfold/2019/01/04/benko-tibor-elarulta-mi-mindent-vesz-ahonvedseg-2028-ig/amp. 


\section{Hungarian Governmental Defence and Military Development Program „Zrínyi 2026”}

The Hungarian government realized that new challenges and threats coming from the international situation, recognized that the Hungarian Defence Forces' stagnation is far too long, and they aren't prepared to face new external threats. The rationale for enactment of the Hungarian Governmental Defence and Military Development Program „Zrínyi 2026” was based on such threats as: migration crisis, annexation of Crimea by the Russian Federation, terrorist attacks in Europe, threats in cyberspace. According to the assessment, the Hungarian Defence Forces was not ready to fight these threats, and react effectively to them. The modernization program adopted in 2016 is a medium-term program lasting ten years. Its objective to increase the potential of the defence forces, and to make these forces a significant element in the region - under the "region" it is understood the Central Europe ${ }^{17}$.

In 2018, 170 years have passed since the establishment of the Hungarian Armed Forces. The currently implemented program "Zrínyi 2026", referring to armed traditions, aims to develop a modern, professional army - with defence capabilities and joint activities with the allied forces. In the opinion of leadership of the Ministry of National Defence, Hungary should maintain the capacity of one of the sager countries in Europe. The determinants of national security remain: a strong State, developed and able to defend the country the Armed Forces, strong and credible alliances, diplomacy of bilateral agreements, high social and professional competence of soldiers, efficient commander and command system of Defence Forces, high morale of society ready to defend the country. For this purpose, before the public, the whole education, upbringing in the family, churches and religious associations, political associations have task to shape pro-defence behaviour. An important element of shaping pro-defence attitudes are the media with their public mission to mobilize the society, inform and explain the directions of the State's defence policy. In presenting the objectives and tasks of the Hungarian defence policy and mentioned program, so far there is no official data on the total costs of modernizing the military forces.

The Military Police Centre of the Hungarian Defence Forces was established in response to the threat coming from the migration crisis in 2016. It meant creating a separate structure of the Military Police. Earlier, the MP was part of the military units, however, after changes, their role and authority grew ${ }^{18}$.

The Minister of National Defence (Istvan Simicskó was the previous minister until the creation of the new Government in 2018) the Government recognized that the most urgent is to increase the potential of the air forces capabilities which already started in 2017. This year, the decision was made to renovate the Mi-24

17 F. Végh, op. cit., p. 334

18 MH Katonai Rendészeti Központ [online], [access: 19.12.2018], https://honvedelem.hu/szervezet/mh_krk. 
and Mi-17 helicopters. These assault and transport helicopters have undergone major repairs in the Russian Federation, which will allow them to prolong their use until the purchase of modern ones with assault and transport capabilities ${ }^{19}$. From 2019, helicopters type H145M will be purchased and start their service. They will be used by special forces and in the reaction to disasters and crisis situations ${ }^{20}$. In 2018, the government signed a contract for the purchase of 16 new Airbus 225M multi-task helicopters. The contract was signed on December 14, and new helicopters will be added to the air fleet in $2023^{21}$. The new purchases shows to NATO that Hungary is ready to be a responsible ally in Europe. Multi-task helicopters increase the capabilities of the Hungarian Air Forces before not seen.

The first of the breakthrough moments of the modernization program was the purchase of two Airbus A319 aircrafts replacing the An-26. Thanks to this purchase, the Hungarian Defence Forces gained the possibility of independent air transport for military and governmental purposes ${ }^{22}$. In terms of increasing the potential, it is necessary to mention the prolongation of leasing the Saab JAS39 Gripen, Swedish production assault aircraft, until 2026. These aircraft also have undergone modernization, which allows them to face modern combat aircraft. Among the modifications, it is worth mentioning the new fire and fighting system, the MS20 software package, the use of the tactical data transmission system Link-16 and the protection of aircraft in the event of mass destruction attack ${ }^{23}$. The Hungarian Gripens not only protect the airspace of Hungary, but also of Slovenia and the Baltic States within the integrated tasks of the NATO member states. The last purchase as part of increasing the air fleet was the purchase of Dassault Falcon 7X plane. This plane will perform mostly diplomatic flights. In the end of 2018, the government decided to increase the fleet with one additional Falcon and Airbus A319 $9^{24}$.

As part of the modernization program, objectives were set not only for the purchase of military equipment but modernizing the Hungarian Defence Forces in all areas. For this purpose, the soldier's salary was increased giving them economical security. They started to repair and renew the barracks and workplaces. In 2017, the uniform was changed to increase the hiding and comfort abilities of the soldiers. These activities are intended to encourage society to reduce the distance between civilians and military, and to encourage young people to join the ranks. For this purpose, the Army conducts intense recruitment to the army and promotes the military career.

19 Feltámad a magyar harci helikopteres képesség [online], [access: 19.12.2018], https://www.jetfly.hu.

20 Folytatódik a haderő fejlesztése - új katonai helikoptereket szerez be a honvédség [online], [access: 19.12.2018], https://honvedelem.hu/cikk/111144_folytatodik_a_hadero_fejlesztese_uj_katonai_helikoptereket_szerez_be_a_honvedseg.

21 Ujabb helikopterekkel bövül 2023-tól a honvédség légiflottája Töretlenül halad a haderöfejlesztési [online], [access: 19.12.2018], https://honvedelem.hu/cikk/113884_ujabb_helikopterekkel_bovul_2023_tol_a_honvedseg_legiflottaja.

22 P. Snoj, I. Simicskó, Történelmi pillanat részesei vagyunk, [online], [access of 19.12.2018], https://honvedelem.hu.

23 B. Bera, BRÉKING: Fejlödnek a magyar Gripenek, [online], [access: 19.12.2018], https://htka.hu.

24 Egy harmadik Airbust és toábbi repülóket is vesz a honvédség, [online], [access: 19.12.2018], https://index.hu/ belfold/2018/12/11/egy_harmadik_airbust_es_tovabbi_repuloket_is_vesz_a_honvedseg/. 
The modernization of equipment and military technology in land forces wasn't as visible as in air forces. For everyday use 550 Suzuki Vitara passenger cars have already been purchased ${ }^{25}$. Modernization assumes also the decommissioning of overused vehicles from the 1990s. The army vehicle park has also been enriched with Currus Aries-Volvo buses ${ }^{26}$. Those coaches are prepared for transporting 40 soldiers with all equipment or alternatively 12 wounded soldiers.

A lot of transport vehicles have increased capabilities of land forces yet from 2018. Among them, worth mentioning is 27 Rába H14 transporters, of domestic production. Special forces had been equipped with ultralight US Polaris MRZR 4 vehicles. These vehicles will be used not only for domestic tasks, but also for humanitarian and peace missions. The advantage of these vehicles is their speed, manoeuvrability and the ability to move in difficult terrain.

A very significant element in the modernization program was the signing of an agreement between the Ministry of National Defence of Hungary and Czech Republic to join the production of firearms in Hungary by Czech license ${ }^{27}$. The new factory was founded in Kiskunfélegyháza and begins the production in 2019. On December 11.2018, 10 thousand firearms were handed over to the army. These arms were not produced from 2018 in the factory, instead of production they started the firearms modulating. The factory produces three types of firearms on the Czech license: CZ BREN 2 type assault rifle, CZ P-09 pistol and CZ SCORPION EVO 3 submachine gun. There are also plans to launch a factory producing of ammunition for the abovementioned weapons.

There isn't much information about the conversion of land forces by using armoured vehicles, tanks and artillery between 2016 and 2018. The fighting methods of land forces used in 2018 was based on overused and outdated equipment. Purchase of new technology was urgently needed, e.g. the 25 Infantry Brigade has 15 T-72M1 tanks, and the main armoured vehicles are the BTR-80s, transferred to the Hungarian Defence Forces as a part of the repayment of debt by the GDR (German Democratic Republic) and the USSR. The artillery capabilities of the army is one of the most obsolete in the army, e.g. the 25 Infantry Brigade has 152-type D-20 guns from 70-80's, and 9M113 anti-tank weapons. There are also the old type BRDM-2 type vehicles (technology from the 60-70's of the XX c.) ${ }^{28}$. The turning point is the agreement signed with the Krauss-Maffrei Wegmann Corporation on the purchase of 44 tanks and 22 self-propelled artillery on December 19, 2018. The media mentions also Leopard 2, and PzH 2000 self-propelled artillery ${ }^{29}$. The question is whether the Ministry of National Defence purchases Leopard from

25 Folytatódik a Magyar Honvédség fejlesztése, [online], [access: 19.12.2018], https://honvedelem.hu/cikk/ 109984_folytatodik_a_magyar_honvedseg_fejlesztese.

26 Sz. Nyulas, Átadták az új katonai buszokat, [online], [access: 20.12.2018], https://honvedelem.hu.

27 Á. Draveczki-Ury, Új mérföldkő a haderőfejlesztésben [online], [access: 20.12.2018], https://honvedelem.hu.

28 MH 25. Klapka György Lövészdandár [online], [access: 20.12.2018], https://hu.wikipedia.org.

29 MTI, Új harckocsikat vesz Magyarország - így nézhetnek ki [online], [access: 20.12.2018], https://www.portfolio.hu/vallalatok/uj-harckocsikat-vesz-magyarorszag-igy-nezhetnek-ki.308333.html. 
the $2 \mathrm{~A} 4$ series - which in 2018 was already considered outdated - in comparison to the newer series of types 2A5-2A7. Among the experts, Leopards best frequent sales are the series $2 \mathrm{~A} 4$ and $2 \mathrm{~A} 6$. The purchase of these tanks has risen above the average the potential for ground forces, with no previously experienced level.

Based on the statement of the Minister of National Defence (4 January 2019) 12 Leopard 2A4 will be leased by the army until they receive the 44 new Leopard $2 \mathrm{~A} 7+$ tanks which are the most modern versions of this German tank. These tanks are to be brought in at the earliest in 2025. There was a ministerial decision that the next step must be taken to purchase new armoured vehicles, with readiness to take action against modern threats, and provide protection for the transport of the army ${ }^{30}$. Analysing this purchase, we should calculate the costs of maintenance and repair of this vehicles. By purchasing the newest German technology, the capabilities of the land forces will grow drastically, showing as mentioned before, that the Hungarian Defence Forces made real steps to modernize the weaponry.

It follows from the above that the modernization of military weaponry and technology in 2018 was at a new level not seen from the 1990s. The launch of defence production and the purchase of new equipment are the main objectives of the modernization program started in 2016. This program is in the initial phase, but the changes taking place in the Hungarian Defence Forces clearly show that they have begun increasing its capabilities.

\section{Conclusions}

The main objective of the Hungarian Governmental Defence and Military Development Program "Zrínyi 2026” is to raise the potential of the Hungarian Defence Forces to become a significant force in the region. The above-described changes in technology and structure are to face today's challenges and threats in the region. Analysing the changes, it should be underlined that this is the beginning of this medium-term modernization program. What will this mean for the future can't be currently forecasted because of the lack of information. The only factual forecasts can be made looking at change and purchase of new technologies in place of the outdated and overused ones.

In order to achieve the goals, set by the Government, an increase in the defence budget is inevitable. This is the reason for the intended 2\% of GDP for the military expenditures, as also decided at the NATO Summit. Reaching this threshold shows that in the Alliance the Hungary is ready to execute its goals and threshold, as the responsible member of the organization.

The amendment to the Act created a new command structure of the Hungarian Defence Forces. The centralization of the command and synthesis of activi-

\footnotetext{
30 Statement of the Minister of National Defence in one of the Hungarian radios (InfoRádió) [online], [access: 06.01.2019], https://infostart.hu/belfold/2019/01/04/benko-tibor-elarulta-mi-mindent-vesz-ahonvedseg-2028-ig/amp.
} 
ties by Commander of the Hungarian Defence Forces, the Chief of the General Staff, is the most important step. The amendment unambiguously shows that the Minister of National Defence will manage, and the Commander will command, and lead the Hungarian Defence Forces. These changes could have a good impact on the military subsystem, because of the speed and efficiency of taking decisions at the central level.

The contracts for purchasing weaponry determines series of activities for the highest and lowest level of command. Soldiers using new and modern equipment's should undergo serious training in order to prepare them for the time of war, and to use them most effectively and accuracy. For this purpose, it is a good decision to lease Leopard 2A4 tanks in order to train tankers from the old soviet T-72 tanks for today. Similarly with the contract for purchase of multi-task helicopters Airbus $\mathrm{H} 225 \mathrm{M}$, that also includes construction of the new Airbus factory in Hungary. The company plans here to start production of parts for the above-mentioned helicopters, and others.

What is important, however, is to remember about the impact of Hungary's armaments on security in the region, and whether these changes will really be able to face the challenges and threats present in the region, and in the world. In the Correlates of War Project there is a conclusion that one of the elements influencing or stopping the outbreak of war, is the armament of states.

\section{LITERATURE}

[1] Constitution of Hungary: [online], [access: 17.12.2018], http://libr.sejm.gov.pl/tek01/ txt/konst/wegry2013.pdf.

[2] CXIII National Defence Act, Hungarian Defence Forces and measures taken during the crisis states [online], [access: 17.12.2018], https://net.jogtar.hu/ jogszabaly?docid=A1100113.TV.

[3] Holló J.F., Isaszegi J., NÉGyesi L. (edit.), A Magyar Honvédség 170 éve, Wyd. Zrínyi, Budapest 2018.

[4] http://www.kormanyhivatal.hu/ official website of the Hungarian Government.

[5] https://htka.hu

[6] https://www.jetfly.hu

[7] NATO Summit guide, Brussels 2018, p. 310, https://www.nato.int/nato_static_fl2014/ assets/pdf/pdf_2018_07/20180718_180711-summit-guide-brussels.pdf.

[8] Orosz Z., Szabó Szabóné A., Resperger V. (edit.), A Magyar Honvédség évkönyve 2016, Wyd. Zrínyi, Budapest 2017.

[9] PAty A., TéGlÁsi A. (edit.), Államtan és a Magyar Állam szervezete, Wyd. NKE, Budapest 2013.

[10] Szenes Z., Honvédelem - védelempolitika, Wyd. Dialóg Campus, Budapest 2017.

[11] Wróblewski R., Wyręвeк H. (edit.), Determinanty bezpieczeństwa militarnego, Wyd. Uniwersytet Przyrodniczo Humanistyczny w Siedlcach, Siedlce 2016. 
[12] www.honvedelem.hu official website of the Hungarian Defence Forces.

[13] www.index.hu

[14] www.infostart.hu

[15] www.parlament.hu official website of the Parliament.

[16] www.portfolio.hu

\section{WĘGIERSKI PROGRAM ROZWOJU ARMII I OBRONNOŚCI „ZRÍNYI 2026” JAKO ODPOWIEDŹ NA NOWE ZAGROŻENIA W REGIONIE}

Streszczenie. Artykuł ma na celu przedstawienie uchwalonego w 2016 r. Węgierskiego Rządowego Programu Modernizacji Wojska „Zrínyi 2026”. Autor skupia się zarówno na zmianach technologicznych i w sprzęcie wojskowym, jaki i na zmianach organizacyjnych oraz strukturalnych. W tych ramach przedstawiona została analiza budżetu obronnego Węgier wraz z prognozami do roku 2024 Autor przekrojowo opisuje istniejącą od 1 stycznia 2019 r. strukturę wojskową Wojska Węgierskiego oraz adaptacje wynikające ze współczesnych zagrożeń w regionie.

Słowa kluczowe: Wojsko Węgierskie, program modernizacyjny, budżet obronny, podsystem militarny, bezpieczeństwo. 